\title{
BROADCASTING POLICY AND A UNIVERSITY OF THE AIR
}

A

LTHOUGH the White Paper A University of the A Air was mentioned in the House of Commons in the debate on broadcasting policy on March 3, that debate was concerned with broadcasting policy generally. Of special interest in the debate was the reply of the Postmaster-General, Mr. A. Wedgwood Benn, who stressed the central problem of the finances of the British Broadcasting Corporation. Mr. Benn pointed out that the Corporation could no longer rely on increased revenue from a growing number of television licences. Because the 1954 Act left the Corporation dependent on a fixed licence to compete with programme contractors granted a monopoly of advertising revenue and for whom expansion was highly profitable, it looked as if the Corporation would require a further increase of $£ 1$ in the licence in 1966 and another in the next 4 years. Furthermore, for a comprehensive system of local broadcasting a further $5 s$. would be required-it was estimated that licence evasion already amounted to the equivalent of an extra 10s. licence. After referring to such alternatives as increased borrowing or an Exchequer grant, Mr. Benn said that the Corporation had now put before the Government proposals which it believed could or might stabilize the licence $f \Theta \theta$ for another 2 years or more without cutting its services; while considering these proposals, the Government was dealing further with the evasion of licences. He also affirmed the Government's intention to introduce legislation to deal with pirate radio companies. On hours of broadcasting, a final decision would have to wait until further discussions had been held with the Corporation.

Mr. Benn stated that he thought that the role of publishing in broadcasting, making outlets available for independent experimental education programmes, was important-it was here that he mentioned the University of the Air. He indicated that he was discussing with the Independent Television Authority the possibility of opening up outlets, under a provision in the 1964 Act, for universities such as Strathclyde, and independent institutions and units which at present had no access to the television screen. Mr. Benn welcomed the development of closed-circuit television and regarded the awakening of public understanding of the possibilities of local radio as a most significant development. Besides the B.B.C., the commercial radio companies, and genuine community stations, including local authorities, were interested in local stations, and the White Paper on a University of the Air also referred to the part which local stations might play. As to a fourth channel, Mr. Benn estimated that this could involve a capital cost of about $£ 30$ million and many million pounds a year to run. Here was a question of priorities. On colour television, the Government had accepted the advice of the Television Advisory Committee to use the PAL system of trans- mission on the 625-line standard. Subject to acceptance at the Oslo Conference in June, colour television on B.B.C. 2 would start with about 4 hours a week towards the end of 1967; the cost was estimated at $£ 1-7$ million a year. The cost of sets was estimated at $£ 250$ each initially with a consumer expenditure over the first 3 or 4 years of $£ 100$ million and a net gain of $£ 10$ million in exports.

The White Paper itself* argues that an open university of the air, if it were imaginatively to use new teaching techniques and teacher/student relations, would contribute to the improvement of educational, cultural and professional standards generally, by making available scholarship of a high order to those who look and listen. As is pointed out, it will enable some to accept the full discipline of study and acquire degrees and other qualifications; and it will benefit students in many other parts of the world as well as those studying in the United Kingdom. It is suggested that it will help to meet the urgent need in the developing countries for a highly trained corps of men and women, equipped to provide leadership in national life. At a time when capital resources are scarce, it would provide higher and further education for many without involving vast expenditure on buildings. The proposals are based on the report of an Advisory Committee of which Miss Jennie Lee, Joint Parliamentary Under-Secretary of State, Department of Education and Science, was chairman.

The University would require its own administration centre but would make full use of existing agencies, such as the extra-mural departments of universities, the Workers' Educational Association and local education authorities. It would primarily offer general courses leading to a degree which would be conferred by the university of the air in its own right. A working party should be established to examine the possibility of courses leading to degrees and other qualifications with a technological element. The presentation of courses would involve a combination of television, radio (particularly from local stations), correspondence courses, programmed instruction, tutorials and practicals, short residential courses, and study and discussions at community viewing or study centres. The project requires peak viewing on a television service with national coverage, estimated at least two hours on five evenings a week Enrolment would be open to everyone on payment of a registration fee and no formal entrance requirement would be imposed. The university, which would have its own vice-chancellor and governing body or council, would require a professional staff of about 40-50 and would arrange for regular surveys to assess the effectiveness of courses, and the size and type of audiences following them. *A University of the Air. Pp. 8. (Cmnd, 2922.) (London: H.M.S.o.,
1966.) 1s. $6 d$.

\section{LATEX}

A MEETING of the Phytochemical Group on "The Distribution and Biochemistry of Latex in Plants" was held on January 6 at the School of Pharmacy, University of London. The opening paper on the distribution of latex in the plant kingdom was given by Dr. C. R. Metcalfe (Royal Botanic Gardens, Kew). Latex, produced in specialized laticiferous cells, is found in about 12,000 species, but these are restricted to about twenty scattered families of angiosperms. With the aid of an extensive series of photomicrographs of sections of laticiferous plants, Dr. Metcalfe explained the differences between articulated and non-articulated laticifers and showed examples of their distribution in the plant. Although many articulated laticifers frequently occur in the phloem, non-articulated laticifers are sometimes dispersed throughout all plant tissues including the xylem.

The most important commercial laticiferous plant is Hevea, and the next four papers dealt with aspects of the 